\title{
APPLICATION OF THEORY OF PLANNED BEHAVIOR ON FACTORS AFFECTING PREMARITAL SEXUAL BEHAVIOR AMONG HIGH SCHOOL STUDENTS IN BOYOLALI, CENTRAL JAVA
}

\author{
Bela Novita Amaris Susanto'), Ismi Dwi Astuti Nurhaeni²), \\ Eti Poncorini Pamungkasari3) \\ 1)Masters Program in Public Health, Universitas Sebelas Maret \\ 2)Faculty of Social and Political Sciences, Universitas Sebelas Maret \\ 3)Department of Public Health, Faculty of Medicine, Universitas Sebelas Maret
}

\begin{abstract}
Background: Sexual self-efficacy plays an important role in adolescents' sexual health. Unsafe sexual behavior in adolescents increases the risk of sexually transmitted infections (STI) and unintended pregnancy. This study aimed to determine factors affecting premarital sexual behavior among high school students in Boyolali, Central Java, using Theory of Planned Behavior.

Subjects and Method: This was a cross-sectional study carried out at senior high schools in Boyolali, Central Java, from October to December 2018. A sample of 200 students was selected by cluster random sampling. The dependent variable was premarital sexual behavior. The independent variables were knowledge on sexual behavior, attitude, selfefficacy, religion, parental supervision, access to information, and subjective norm. The data were collected by questionnaire and analyzed by a multiple logistic regression.

Results: Premarital sexual behavior decreased with high knowledge $(b=-3.33 ; 95 \% \mathrm{CI}=-$ 5.88 to $-0.79 ; \mathrm{p}=0.010)$, positive attitude $(\mathrm{b}=-5.16 ; 95 \% \mathrm{CI}=-8.63$ to $-1.70 ; \mathrm{p}=0.004)$, strong self-efficacy $(\mathrm{b}=-4.65 ; 95 \% \mathrm{CI}=-7.37$ to $-1.94 ; \mathrm{p}=0.001)$, good religion and belief $(\mathrm{b}=$ -3.95; 95\% CI= -6.82 to $-1.10 ; \mathrm{p}=0.007)$, high parental supervision $(\mathrm{b}=-3.70 ; 95 \% \mathrm{CI}=-$ 6.60 to $-0.80 ; \mathrm{p}=0.012)$, high exposure to information $(\mathrm{b}=-3.61 ; 95 \% \mathrm{CI}=-6.10$ to $-1.12 ; \mathrm{p}=$ $0.004)$, and unsupportive subjective norm $(\mathrm{b}=-2.43 ; 95 \% \mathrm{CI}=-4.60$ to $-0.25 ; \mathrm{p}=0.029)$.

Conclusion: Premarital sexual behavior decreases with high knowledge, positive attitude, strong self-efficacy, good religion and belief, high parental supervision, high exposure to information, and unsupportive subjective norm.
\end{abstract}

Keywords: Premarital sexual behavior, Theory of Planned Behavior

Correspondence:

Bela Novita Amaris Susanto. Masters Program in Public Health, Universitas Sebelas Maret, Jl. Ir. Sutami 36 A, Surakarta 57126, Central Java, Indonesia.

Email: bnamaris@gmail.com. Mobile: +6285788844440

The $5^{\text {th }}$ International Conference on Public Health

Best Western Premier Hotel, Solo, Indonesia, February 13-14, 2019 | 170

https://doi.org/10.26911/theicph.2019.02.15 